Revista de Antropología Social

ISSN: 1131-558X

http://dx.doi.org/10.5209/rev_RASO.2016.v25.n1.52630

\title{
El “Animanazo". Canción y memorias. Expresiones y soportes culturales en la reconstrucción del pasado de una localidad del norte argentino
}

\author{
Andrea Jimena Villagrán ${ }^{1}$; Irene López ${ }^{2}$
}

Recibido: 18 de marzo de 2015 / Aceptado: 4 de abril de 2016

Resumen. Este trabajo toma como punto de partida el contexto de producción y situaciones locales de apropiación y resignificación de la canción folklórica "Fuego en Animaná" —así como el reclamo y movilización que esta evoca ("El animanazo") — para examinar los distintos mecanismos y soportes mediante los cuales una población se relaciona con un acontecimiento de su pasado comunitario, identificándose con éste y apropiándoselo en claves específicas.

Se combinan el análisis discursivo de la canción y de entrevistas a pobladores y participantes en el evento con la reconstrucción mediante observación etnográfica de instancias de uso de esta canción.

Palabras clave: memoria social; canción; análisis del discurso.

\section{[en] "Animanazo". Song and memories. Cultural expressions and movements in the reconstruction of the past inside a north Argentinian town}

\begin{abstract}
This article analyses the context of production and local situations of appropriation and resignification related to the folk song "Fire on Animaná" as well as the request and mobilization ("The animanazo") provoked by this song in order to examine different mechanisms and foundations by which a population connect with an event from its community past, identifying with this and taking it in a specific way.

In this article we combine discourse analysis of the song and of interviews to participants in this event with the reconstruction - through ethnographic observation — of how to use this song.
\end{abstract}

Keywords: social memory; songs; discourse analysis.

Sumario. 1. Introducción. 2. Cantar con fundamento: la trama política y social de la canción. 3. Los relatos y la trama de la vida. 4. Conmemoración: canción y memorias. 5. Celebración y re-significación. A modo de comentarios finales. 6. Referencias bibliográficas. 7. Anexos.

Cómo citar: Villagrán, A. J., López, I. (2016) El “Animanazo”. Canción y memorias. Expresiones y soportes culturales en la reconstrucción del pasado de una localidad del norte argentino, en Revista de Antropología Social 25(1), 171-194.

\footnotetext{
$1 \quad$ ICSOH, UNSa, CONICET (Argentina) ajvillagran@gmail.com

2 ICSOH, UNSa, CONICET (Argentina) irenlopez@hotmail.com
} 


\section{Introducción}

En este trabajo proponemos indagar las relaciones entre pasado y presente desde el estudio focalizado en una canción, reconstruyendo su contexto de producción, las distintas formas locales de apropiación y su resignificación en el contexto de la conmemoración del evento al cual esta canción se refiere. Esto permite derivar la exploración hacia el modo en que se relaciona un grupo social con un acontecimiento de su pasado comunitario, recuperando voces, posiciones y tensiones, así como las distintas dimensiones que conforman la trama compleja en la que los mecanismos sociales de la memoria y la canción se entretejen, en la medida que ésta opera como un soporte y vehículo en la construcción y recreación de sentidos sobre "la historia" ${ }^{3}$ de un lugar o comunidad.

El análisis aborda simultáneamente la canción "Fuego en Animaná", el evento ${ }^{4}$ al cual ésta remite —el "animanazo" - y el ritual de conmemoración al cumplirse cuarenta y un años, el 19 de Julio de 2013. Se consideran también relatos y narraciones de los habitantes de la localidad en torno al evento, ya que constituyen diferentes registros que entran en juego en su reconstrucción.

En Julio de 1972, un grupo de aproximadamente setenta trabajadores de la finca y bodega Animaná, con la conducción del Sindicato de Obreros y Empleados Vitivinícolas, iniciaron una serie de medidas en reclamo por el pago de salarios adeudados. Las acciones que realizaron incluyeron, entre otras, el corte de una ruta provincial (interrupción del tránsito en la carretera), el cobro de peaje, la "toma" del edificio municipal y la destitución del Intendente, una movilización hacia la vecina localidad de Cafayate y la organización de ollas populares. Todas estas acciones alcanzaron visibilidad pública a través de medios de difusión provinciales y nacionales bajo la denominación de "animanazo".

Pese a que cobró tal trascendencia, existe un único estudio social que hace referencia a este suceso y lo considera como un episodio dentro del conjunto de "levantamientos populares" que marcaron los primeros años de la década del 70 en Salta y la Argentina ${ }^{5}$, momento signado por la generalización de reclamos sociales en todo

3 Ello se orienta desde una perspectiva que entiende a la historia como una construcción social inmersa en un campo de fuerzas, anclada a específicas formas de producción y prácticas de historización en las que intervienen diversos y desiguales agentes y no exclusivamente las voces de especialistas e historiadores, desplegándose y poniéndose en juego categorías culturales y temporales, nociones particulares de agencia y causalidad, criterios de legitimidad, autenticidad, verdad y propiedad. En esta perspectiva se pueden señalar los trabajos de M. Sahlins [1985(1997)] y R. Trouillot (1995) y, para el caso de la antropología argentina, se pueden mencionar a Guber (1994) y Briones (1994).

4 Empleamos evento en el sentido de evento crítico (Das, 1996). Tal como la autora lo propone, éstos se definen por los efectos re-configurantes que producen, por su potencial arrollador, porque después de que suceden nada vuelve a ser como antes. La particularidad que los caracteriza es que tras ellos se desencadenan y manifiestan nuevos modos de acción que redefinen categorías tradicionales, suponiendo que entonces nuevas formas de acción también son adquiridas por los actores (traducción propia). Por su potencial analítico el evento es tomado como una puerta de ingreso a los procesos sociales, habilitando a la vez la integración de la experiencia y vivencia de los sujetos, penetrando desde la perspectiva y re-elaboración subjetiva de los actores sociales intervinientes. Este evento, si bien es construido como tal y seleccionado desde la perspectiva del investigador, a la vez también es identificado y reconocido, considerado significativo desde la perspectiva de los actores, quienes le atribuyen un lugar de referencia en sus vidas y en la historia del pueblo. Los actores elaboran y construyen parámetros de ordenamiento de los sucesos desde los cuales establecen una relación específica entre pasado y presente, marcan singularmente los quiebres entre un antes y un después. En ello ponen en juego operaciones de temporalización, explicación e interpretación. Esto fue trabajado en Villagrán $(2012,2014)$.

$5 \quad$ Ver R. D. Scotorín, 2007. 
el país. Estos, en cierta medida, se inician con "el Cordobazo" de mayo de 1969 y abren un ciclo de movilizaciones y puebladas de diverso matiz, que adoptarán formatos específicos de acuerdo al arco de organizaciones políticas intervinientes en cada caso, incluyendo las que se encaminaron por la vía de la lucha armada. Tanto en las principales ciudades como en las provincias alejadas de la capital del país, las medidas de protesta involucraron diversos actores: estudiantes, obreros industriales y campesinos, entre otros ${ }^{6}$. Healey, plantea que el período comprendido entre 1969 y 1973 estará definido por un cierto desplazamiento del eje de la vida política hacia el interior del país; las rebeliones de entonces habrían conferido al interior un protagonismo nunca antes visto en la historia política de Argentina (Healey, 2003: 172). En ese lapso se intensificarán acciones y expresiones que remiten a un clima de violencia cuyos antecedentes pueden ya rastrearse en 1955 con la denominada "Revolución libertadora", y en episodios de golpes militares desde las primeras décadas del siglo XX. Estos antecedentes van generando las condiciones de posibilidad sobre las que se afirmarán las prácticas sociales genocidas y el terrorismo de estado durante la dictadura militar de $1976^{7}$. Todo ello, en un clima de creciente conflictividad social, de debilitamiento de la democracia producto no solo de la proscripción de una fuerza política mayoritaria — como el partido peronista - sino también por la alternancia permanente entre gobiernos civiles y militares. En este escenario se produce la aparición de nuevas formas de protesta social inéditas y la emergencia de nuevos actores políticos y sociales (James, 2003:11).

Entre esas nuevas formas de protesta social se encuentra la movilización de los trabajadores vitivinícolas de Animaná, localidad situada en los Valles Calchaquíes ${ }^{8}$ de la provincia de Salta, que se ubica en el extremo norte de Argentina, en una zona de clima seco y de fuerte irradiación solar, ambiente propicio para el cultivo de vid y la elaboración de vinos. Por entonces estaba conformada por una población aproximada de mil habitantes, vinculados a la vitivinicultura de diversos modos en tanto esta constituía la principal actividad económica de la región.

El mismo año en que sucede el "animanazo", el poeta Armando Tejada Gómez" y el músico César Isella ${ }^{10}$ componen "Fuego en Animaná", una canción que, basada en este acontecimiento, adquiere el carácter de primer homenaje a esta movilización

6 La experiencia del "cordobazo" de 1969, tuvo antecedentes previos en el denominado "correntinazo", habrá episodios de ese carácter en el denominado "Rosariazo" (que tiene como epicentro a la ciudad de Rosario de Santa Fé y se expresa en profundas protestas callejeras entre mayo y septiembre de ese año) y en el "mendozazo" o "mendocinazo", que tuvo lugar en la ciudad de Mendoza el 4 de Abril de 1972. Asimismo con el "tucumanazo", que mantuvo una aguda movilización obrero-estudiantil entre 1969 y 1972 en Tucumán, y en Salta, en noviembre de 1970, hubo expresiones de protesta que se denominaron "salteñazo".

7 Entre 1971 y 1973, se encuentra al mando del gobierno de facto el general Alejandro Lanusse, quien, tal como sostienen Cavarozzi y Gutiérrez, habría tenido el doble propósito de garantizar la continuidad del poder de las fuerzas armadas y, a la vez, reincorporar al peronismo en la vida política del país (1999:13).

8 Región ubicada hacia el sudoeste de la provincia de Salta, compuesta por los departamentos de Cafayate, San Carlos, Molinos y Cachi. La localidad de Animaná se encuentra dentro de la Jurisdicción de San Carlos, distante a $8 \mathrm{kms}$ de Cafayate, que es la ciudad más importante.

9 Poeta mendocino nacido en 1929. Desarrolló una extensa producción de canciones y una importante obra poética y literaria. A modo de referencia, mencionamos algunos de sus libros: Pachamama (1954), Antología de Juan (1958), Profeta en su tierra (1968) Canto popular de las comidas (1974, $1^{\circ}$ Premio de Poesía del Concurso Literario de Casa de Las Américas).

10 Cantante y compositor salteño, inició su carrera en 1954 integrando el grupo Los sin nombre. De 1956 a 1966 forma parte de las voces Los Fronterizos, año en que comienza su carrera como solista. En 1963, durante un viaje a Mendoza, contacta con Armando Tejada Gómez, Oscar Matus y Mercedes Sosa, adhiriéndose a los postulados del Manifiesto del Nuevo Cancionero. 
social. El evento, interpretado por los autores como altamente significativo en un contexto de luchas y reivindicaciones sociales, queda así inscripto en un registro cultural específico, la canción popular. Perteneciente al género que la industria de la música reconoce como folklore musical argentino ${ }^{11}$, esta composición se inscribe en la llamada canción de "protesta" y militante (Molinero, 2011) desarrollada en el marco de una tendencia estética y política que, hacia los años 1960 y 1970, significó un momento de renovación musical y poética de alcance nacional y latinoamericano, caracterizado por una creciente orientación ideológica de izquierdas y una marcada vocación latinoamericanista. En dicha orientación se tornan preponderantes los postulados acerca del compromiso social del artista junto a la relevancia otorgada a la calidad estética de las producciones y a su potencialidad política. En el campo del folklore argentino, la renovación de los paradigmas discursivos, las estrategias retóricas, los tópicos poéticos y el lenguaje musical convergen en el movimiento denominado "Nuevo Cancionero" (Díaz, 2009) ${ }^{12}$, integrado por Armando Tejada Gómez, Javier Matus, Tito Francia y Mercedes Sosa, entre muchos otros $\operatorname{artistas}^{13}$. La canción figuró entre la lista de temas prohibidos durante la dictadura militar en Argentina $^{14}$. Esta situación constituye un aspecto crucial en la circulación de la canción, sobre todo en los usos y apropiaciones que, en un contexto político cultural, llevan a cabo determinados grupos y sujetos como parte de los procesos de activación y reconfiguración de las memorias asociadas al "animanazo".

La perspectiva de análisis contempla distintos registros y niveles que posibilitan recomponer las tramas de vinculaciones entre elementos y figuras construidas en esa canción y las referencias simbólicas mediante las cuales los pobladores de Animaná evocan ese evento y lo re-significan inscribiéndolo en su presente. Para ello, se conjugan diversas estrategias que van del análisis discursivo a la reconstrucción etnográfica de espacios y situaciones sociales de uso y circulación de la canción, en especial en el contexto ceremonial del primer acto conmemorativo.

Entendemos que toda canción constituye una forma de producción cultural compleja en la que intervienen distintos agentes: músicos, poetas, intérpretes, arregladores, receptores (Díaz, 2009; López, 2013) y que, en virtud de los múltiples códigos que operan en un evento musical, el sentido no se localiza sólo al interior de los

11 A diferencia de los rasgos señalados por los folklorólogos, el tipo de producción que acá consideramos no constituye una manifestación rural, anónima y colectiva sino una canción de autor de origen urbano articulada en torno al mercado y a la industria cultural. Entre los años 1930 y 1940 se produce un movimiento de alcance nacional que Ricardo Kaliman define como "folklore moderno", entendiendo por tal a las formas que, aunque derivadas de las prácticas rurales, ingresaron a los circuitos urbanos y se difundieron a través de los medios masivos (2003b: 26). Otras categorías propuestas para distinguir este fenómeno son las de proyección folklórica (Cortazar, 1967) y folklore mediático (Chamosa, 2012). Para comprender la conformación y desarrollo del folklore como campo de producción cultural, social y discursiva en la Argentina, ver Chamosa (2012), Díaz (2009) y Kaliman, (2003a, 2003b, 2007, 2010).

12 C. Díaz (2009) distingue dos paradigmas discursivos en el campo del folklore argentino, uno de ellos construido sobre una idealización del gaucho y del paisaje rural, con una base ideológica conservadora y tradicionalista, que denomina "paradigma clásico" y, otro, imperante en los años 60, de renovación y con una orientación política, ideológica y estética opuesta. R. Kaliman (2007), por su parte, reconoce la simultaneidad de dos tendencias retóricas, una de ellas esencialista y la otra que apunta a la estilización.

13 El manifiesto del Nuevo Cancionero fue difundido en el año 1963 en la provincia de Mendoza, Argentina.

14 El Comité Federal de Radiodifusión (COMFER), dependiente de la Presidencia de la Nación, se encargaba durante el denominado "Proceso de reorganización nacional" — que se inicia el 24 de Marzo de 1976 con el golpe de estado a un gobierno constitucional y democrático - de confeccionar listas de canciones cuyas letras eran consideradas "no aptas para ser difundidas por los servicios de radiodifusión". 
materiales musicales sino en la trama de los discursos contradictorios a través de los cuales la gente le da sentido (S. Frith, 2003; Vila, 1996), como también en las peculiares formas sociales de uso y apropiación en contextos específicos. Como sostiene S. Frith (2003), la música es particularmente poderosa en su capacidad de interpelación porque trabaja con experiencias emocionales intensas permitiendo una apropiación para uso personal (Vila, 1996) y convirtiendo, según determinadas coyunturas, a ciertas producciones en soportes privilegiados para los procesos de construcción de memorias y de sentidos de pertenencia.

\section{Cantar con fundamento: la trama política y social de la canción}

Ayer nomás ardió el pueblo por la tierra y por el pan, y la fogata en el valle no estaba por sólo estar.

Fuego en Animaná

El fragmento citado remite al conflicto desencadenado en el "animanazo" y condensa núcleos de sentido significativos en torno a la imagen simbólica del fuego y de un pueblo en "llamas" por el reclamo social; la función que cumple este recitado en el conjunto de la canción, evocando el levantamiento, es asimismo el indicio de una concepción del cantor que se erige como portavoz de las reivindicaciones populares y del canto como forma de darles visibilidad y entidad artística. La primera grabación de esta canción es interpretada por César Isella y Los Trovadores en el Long Play (LP) A José Pedroni, editado en 1972. Ese mismo año recibe el segundo premio del Festival de la Patagonia en Punta Arenas, Chile. La proximidad entre el evento, la composición de la canción y su grabación permite inferir que la misma fue compuesta al calor de los hechos, siendo registrada un año más tarde en la Sociedad Argentina de Autores y Compositores de Música (SADAIC), año en el que también fue editada la partitura por Editorial Lagos.

Armando Tejada Gómez y César Isella desarrollaron una fructífera dupla compositiva de la que dan cuenta numerosas canciones, entre ellas "Fuego en Animaná", "Triunfo agrario", "Canción de las simples cosas" y "Canción con todos" — tal vez una de las obras más conocidas y difundidas, no sólo de esta dupla sino de la tendencia militante y americanista ${ }^{15}$. Las composiciones que integran el trabajo discográfico en el que se interpreta "Fuego en Animaná" incluyen otras dos canciones de igual autoría: "Triunfo agrario" y "Resurrección de la alegría", junto a otras que se orientan en el mismo sentido: "Canción para el fusil y la flor" (Sánchez/Palomo) y

15 “Canción con todos” fue compuesta en 1969 e incluida en el LP Canción con todos grabado entre 1970 y 1971. En 2012 fue declarada Himno de Latinoamérica por las Naciones Unidas. Otras composiciones conjuntas son "Canción de la ternura", "Canción de las simples cosas", "Canción de lejos", "Canción del forastero", "La Mamancy", "Luna de Córdoba", "Muchacha del sur", "Paloma y laurel", "Canción de la alfarera", "Triunfo agrario"; "Resurrección de la alegría", "Hombre en el tiempo" (canción), "Breve historia de Juan" (zamba) en LP Hombre en el tiempo de 1971. Además de la labor compositiva, en 1970 compartieron la organización del espectáculo América Joven. 
"El regreso del juglar" (Isella/Lima Quintana). Como puede observarse, todas remiten a reivindicaciones políticas, sociales e ideológicas vigentes en el campo intelectual y social de esos años. El lado 2 del LP contiene un breve texto introductorio de Amando Tejada Gómez en el que se expresa la concepción política del rol del cantor y de su canto:

El juglar ha vuelto. Desde el remoto tiempo en que su canto era pregón de júbilo por las aldeas, ha vuelto. Pero ahora avanza esclarecido por el alto magisterio de cantar un tipo de canciones que no tienen la mera función de distraer, sino también la de agitar la conciencia activa de una Argentina joven ${ }^{16}$. Porque joven es todo aquel que tiene el espíritu intacto para el asombro. Y ese juglar indiscutido que es César, regresa ahora en esta nueva obra con un puñado palpitante de nuevas convocatorias para un país que quiere respuestas de su canto. Que busca en la obra de autores e intérpretes el vital contenido de su vida en movimiento. A esa necesidad responde Isella con una búsqueda permanente, con un trabajo incesante de composición junto a los poetas de la patria de hoy, actitud que convierte cada disco suyo en un hallazgo nuevo, en un objeto vivo que nutre la ansiedad estética de nuestras juventudes. En la obra y el canto de César Isella está claro que no hay forma sin contenido ni contenido sin forma.

Advertimos, así, una orientación de sentido que abarca no sólo al disco como obra unitaria que engloba las canciones en él contenidas, sino a toda la producción del cantautor, que se inscribe en una corriente estética que lo legitima, exaltando el potencial político del cantor, del poeta, de su canto, su función y su mensaje. Ello queda claro en la oposición establecida entre un tipo de canción destinada a "distraer" y aquella otra que, desde el "alto magisterio" del arte, aspira "agitar conciencias". A la vez, no sólo se trata de retratar al hombre contemporáneo y estar en consonancia con sus luchas sino que también se procura alcanzar una circulación popular, provocar la identificación entre lo que estas canciones ofrecen y lo que el pueblo - "nuestras juventudes" - pide y necesita. En ese contexto se actualiza la discusión en torno al "contenido" - artístico y, al mismo tiempo, político y testimonial- de la canción. En esa línea, una categoría en circulación entre intérpretes, compositores, cronistas y público, es la de "canción con fundamento", distinguible de la canción "pasatista", "comercial", "ligera", "banal" o "sin contenido" 17.

Tejada Gómez expresará esta idea con especial énfasis, afirmando que "la canción es una forma de lucha" y que una obra adquiere no sólo un valor artístico sino también testimonial y de denuncia. Sobre su LP Canción con todos sostiene que se trata de "La crónica cantada de un tiempo nacional y americano de soñar, cantar, padecer, luchar y reír a patria llena, de pie en la esperanza" ${ }^{18}$. Esta concepción del arte y de la

16 El subrayado es nuestro.

17 Si bien se ponen en juego valores propios del campo artístico, en este caso hay una inflexión que aspira a un tipo de circulación y consumo no elitista. Estas oposiciones están vigentes en el momento de producción de esos años con un énfasis particular, ya que en 1972 se conmemoraba el "año Hernandiano", en homenaje a la publicación de la primera parte de El gaucho Martín Fierro escrito por José Hernández en 1872. Una nota de la revista Folklore (mayo de 1972) titulada "En el año hernandiano...cantar con fundamento, una utopía” plantea una polémica entre la canción con fundamento y la canción comercial, realizando una clara vinculación con la tradición del contar cantando inscrita en la gauchesca, concretamente en el Martín Fierro (Revista Folklore, N 209, Mayo de 1972).

18 Texto incluido en la presentación del LP Canción con todos de 1971. Se puede consultar en http://www. tejadagomez.com.ar/ 
poesía como compromiso social se complementa con la práctica política partidaria ${ }^{19}$ y da cuenta de las tensiones en el interior del campo del folklore argentino, en el que se dirimen posiciones divergentes respecto de las representaciones de lo popular, lo nacional y lo tradicional. Como sostiene C. Díaz (2009), estas representaciones, y las concepciones acerca del canto, difieren de acuerdo a los paradigmas discursivos dominantes en determinados momentos sociohistóricos. En este caso, la convicción política acerca del rol del cantor y su arte, como forma de acompañamiento de los procesos sociales de reivindicación de derechos de grupos históricamente marginados - trabajadores, campesinos, indígenas-, se corresponde con una lucha por la legitimidad de las representaciones e identidades en el seno del campo del folklore, en cuyo desarrollo había sido dominante una perspectiva tradicionalista y conservadora, afín a posiciones ideológicas de derecha. Por el contrario, como ya señalamos, la vertiente en la que se inscriben la canción y sus compositores se fundamenta desde postulados afines a corrientes ideológicas de izquierda.

"Fuego en Animaná" forma parte de ese ideal de la canción que aspira a convertirse en crónica, testimonio y forma de lucha. El interés por componer una canción sobre el "animanazo" se enmarca en esa concepción y da cuenta la sensibilidad de sus autores hacia las reivindicaciones $\operatorname{sociales}^{20}$ y de la función que éstos se atribuyen como cronistas de los conflictos humanos. Sin embargo, dado que la letra no ofrece referencias explícitas ni aporta datos concretos sobre el suceso, la canción podría interpretarse sin establecer vinculación con las acciones llevadas a cabo por los trabajadores vitivinícolas de la finca Animaná, ya que el recitado, que invoca al levantamiento y remite a la acción de la fogata, no se incluye en todas las interpretaciones de la canción ${ }^{21}$. No obstante, opera como un testimonio, crónica y apología de la protesta social.

La dimensión combativa, militante y testimonial de la canción radica por un lado, en la impugnación que la letra produce respecto de las representaciones dominantes sobre el habitante de los Valles y, por otro, en la referencia simbólica anclada a las figuras del fuego y la olla, en la configuración rítmica de la canción y en la contundente afirmación de una pertenencia al lugar. Su potencialidad crítica se despliega al tensionar dos representaciones antagónicas del espacio calchaquí y de los sujetos que lo habitan. A diferencia de las perspectivas ligadas a una concepción esencialista que subsume a los sujetos en el paisaje y los deshistoriza, la que predomina en esta canción pone de relieve la agencia de los actores y su potencial transformador, a la vez que reivindica al Valle Calchaquí como escenario de conflictos, movilización y protesta. Así es que esta canción confronta con toda una serie de producciones cul-

19 En 1958 Tejada Gómez actuó como diputado provincial por la Unión Cívica Radical Intransigente (UCRI), un ala del radicalismo liderada por Arturo Frondizi y poco tiempo después, en 1959 se afilia al partido comunista.

20 Existe información que permite hipotetizar sobre las posibles redes de conexión entre C. Perdiguero, que en ese entonces actuaba como reportero y según relato de protagonistas estuvo en los sucesos, y los compositores de la canción, C. Isella y A. Tejada Gómez.

21 La versión original de César Isella junto a Los Trovadores incorpora el recitado, pero versiones posteriores no (por ejemplo Mercedes Sosa en vivo en Argentina, 1982). En 2011 se edita un disco póstumo de Mercedes Sosa con temas inéditos y censurados por la dictadura militar en Argentina; entre ellos hay una versión de "Fuego en Animaná" grabada en 1975. La interpretación de Roxana Carabajal junto a León Gieco también incluye el recitado. Sin dudas, el recitado constituye el momento más explícito y combativo en la canción, por lo cual su inclusión o no en las interpretaciones es importante, dado que formó parte de las listas de canciones prohibidas por el COMFER y sus compositores recibieron amenazas. Frente a ello, C. Isella decidió exiliarse y A. Tejada Gómez optó por quedarse en el país y registrar su obra mediante el uso del seudónimo Carlos de Mendoza. 
turales consagradas ${ }^{22} \mathrm{y}$, por ello, resulta significativa en el contexto de la producción del folklore musical de Salta. Asimismo, la canción responde a las crónicas periodísticas locales y nacionales que difundieron representaciones en torno a la población de Animaná asociadas a la mansedumbre y la pasividad y que, por tanto, enfatizaron el carácter extraordinario de aquella movilización. Diversos periódicos calificaron el suceso en términos de "Insólita rebelión popular" (La Razón), "La rebelión de los mansos" o resaltaron el carácter pacífico de esta protesta (El Tribuno).

La tensión entre las dos representaciones es perceptible desde el primer verso, donde el enunciador lírico establece una distancia con discursos de amplia circulación materializados en textualidades de diverso alcance - literarios, históricos, filosóficos, periodísticos - que contribuyeron en la configuración de una imagen de los habitantes del Valle Calchaquí arraigada en el mito de la quietud, la mansedumbre, la pasividad y la indolencia, y cristalizada en la metáfora del "solo estar"23. La escritura establece una serie de opuestos que permiten reconstruir esta línea de sentido: luz/oscuridad; atardecer/ amanecer; quietud/ movilización; silencio/ grito; pasividad/ agencia; naturaleza/ historia; estar estando/ "buscando ser". Precisamente, esta última díada articula la tensión entre las dos representaciones que venimos refiriendo: una de ellas vinculada a la pasividad y la quietud en la cual los sujetos se conciben como meros observadores del paisaje o, inclusive, consustanciados con él; la otra, contrapuesta, que enfatiza el rol activo de los sujetos como agentes de transformación y cambio. De tal manera, se configura también una contraposición entre la concepción del habitante calchaquí anclado en el pasado y la representación de un sujeto que proyecta futuro y construye su propia historia.

El primer verso — "Dicen que yo de solo estar fui apagándome" - tiene ese alcance, en el sentido figurado de una vida sin fuego interior, de una existencia sin motivaciones, ni acciones. Los siguientes versos refuerzan este sentido al establecer una comparación con la caída del sol, el atardecer que es el ocaso del día. Lo interesante, es que se trata de un decir ajeno, externo al enunciador — “ellos dicen que...". La respuesta a estas representaciones que vinculan al habitante del Valle a la quietud, la soledad, la "decadencia" — el fuego que se apaga — se hace presente en la segunda parte que, con ritmo de vidala, inicia de esta manera:

\section{Sepan lo que no han sabido \\ que no estoy de sólo estar, \\ que estoy parado en el grito \\ Bagualero del Pujay.}

La contraposición semántica se corresponde con dos secciones rítmicas claramente diferenciadas, huayno y vidala. La elección de esos ritmos musicales no es casual, en tanto operan como estrategia discursiva para la construcción de un lugar de

22 Entre ellas "La arenosa" (Leguizamón/ Castilla), "El seclanteño” (A. Petrocelli), "La Pomeña” (Leguizamón/ Castilla), o "Pastor de nubes" (F. Portal/ Castilla), entre otras. Una excepción es "Tabacalera" compuesta en 1945 por Eduardo Falú (música) y César Perdiguero (letra), que da cuenta de las sufridas condiciones en que se realiza la cosecha del tabaco.

23 Esta construcción simbólica ha sido abonada por los precursores de los estudios folklóricos y circuló por diferentes producciones - literarias, históricas, periodísticas - entre ellas parte de la producción literaria de Manuel J. Castilla. En el terreno filosófico destaca R. Kusch a través de la oposición entre ser/estar. Esto ha sido trabajado en Villagrán (2014b). 
enunciación geocultural ${ }^{24}$. El primero de ellos, de pulsación regular y ritmo movido, es bailable; la vidala, en cambio, de ritmo pausado, es una forma de canto que no se baila. La estructura de la canción introduce, además, un recitado intermedio que cumple la función de ofrecer información - "Ayer nomás ardió el pueblo"-. Emerge acá otra voz enunciativa, una voz que remite al evento, a los reclamos, a las acciones.

El fuego adquiere múltiples significaciones: la vida, la acción, la motivación; la rebelión, la lucha, el poder de la movilización; pero también como forma de construir comunidad, en tanto evoca la práctica de la olla popular, las formas de camaradería, solidaridad y de pertenencia; el fuego, que cumple una función necesaria e imprescindible para la cocción de los alimentos, adquiere simbólicamente la función de crear comunidad y re-ligazón entre los participantes.

La sección siguiente - de igual ritmo y melodía que la primera - pone en juego sentidos que apuntan a un "renacer" - "yo quiero ver en mi país el amanecer"- y a la pertenencia del sujeto a su localidad, que es donde adquiere total sentido su existencia. Así alcanza relevancia la instancia enunciativa desde la primera persona y la reiteración, como repetición significativa de una pertenencia: "Soy de Animaná", y su constante reafirmación - "Es que yo soy ese que soy".

Ser y pertenecer se anudan en esa reafirmación que, luego de la deconstrucción de las representaciones dominantes que justifican o legitiman la pasividad y la quietud, instala otro tipo de idealizaciones: la del pueblo combativo y su capacidad para transformar y/o revertir su situación de opresión. Es aquí donde se trasluce el posicionamiento político de los compositores desde el cual se enaltecen a los protagonistas de aquel evento.

\section{Los relatos y la trama de la vida}

Como señalamos al inicio de este trabajo, el "animanazo" puede concebirse como un evento crítico que marcó un antes y un después en la vida de la comunidad. Esto es lo que puede reconstruirse a través de las voces de algunos de los protagonistas del suceso, como así también de actuales pobladores que aún sin haber participado en él pueden ofrecer alguna información apelando a recuerdos familiares o comentarios que circularon, referidas al conflicto. En el momento en que sucedió, este evento alcanzó transcendencia pública más allá del ámbito local, por la difusión en la prensa pero, posteriormente, quedó en un impasse de silenciamiento, sin habilitarse formas o instancias colectivas de producción y transmisión de relatos, los cuales tal vez encontraron vías de circulación y un espacio de resguardo en el reducido núcleo familiar.

Cuando estalló esta movilización, los trabajadores que mantenían relación con la Finca y Bodega Animaná se vinculaban con sus propietarios de diverso modo; principalmente, en base a acuerdos personales que definían la situación residente o no de los trabajadores, su carácter permanente o temporario, así como el tipo de tarea productiva encomendada. Una clara diferenciación se establecía entre trabajadores de fábrica-bodega y los peones de surco. Los primeros se ocupaban de la elabora-

24 La composición fue registrada como "canción latinoamericana", lo que constituye un rasgo más del americanismo presente en la tendencia del Nuevo Cancionero y de su propuesta de ampliar las fronteras del folklore nacional para inscribirse en un contexto continental. 
ción del vino y su fraccionamiento, generalmente identificados como "bodegueros" o "trabajadores de la fábrica", mientras que los peones de surco desempeñaban las tareas de cultivo y cuidado de las vides en las distintas fases de su ciclo, tales como riego, poda, desbrote y cosecha. La condición y situación variaba entre los trabajadores temporarios, generalmente convocados para una tarea específica y para la temporada de cosecha - entre febrero y marzo - y los permanentes, que tenían una situación de mayor estabilidad. La condición residente habilitaba el derecho a uso de una vivienda y de un terreno para cultivo y crianza de animales de granja destinada al autoconsumo familiar dentro de la finca. El acuerdo de residencia y el ingreso a la finca en ese carácter implicaba el establecimiento de específicos derechos y obligaciones entre los peones y sus familias y los patrones-propietarios ${ }^{25}$.

En las primeras aproximaciones ${ }^{26}$, a través de conversaciones casuales primero y, luego mediante entrevistas pautadas, las respuestas obtenidas respecto al "animanazo" fueron de carácter evasivo, del tipo "no sé", "yo no estaba", "no me acuerdo", "no muchos saben qué pasó", "los que han estado ya se murieron", "pregúntele a don Pedro". Sin embargo, aunque aquellos primeros interlocutores sostuvieron que no podían dar información precisa o contar con detalle o exactitud qué sucedió y cuándo, todos sabían a qué se estaban refiriendo, manejaban algún dato, identificaban aquel suceso y lo asociaban con alguna persona conocida, episodios puntuales o lugares concretos del pueblo, indicando de modo inconexo acciones como "el corte del camino", "el cobro de peaje" y "la olla popular". Incluso, hubo personas a quienes al preguntarles por "el animanazo", repreguntaban "ahhhh ¿"el ollazo"?. En el marco del diálogo que las situaciones de interacción generaron, se mencionó la canción, asociando ésta con aquel evento del pasado pero sin mayores especificaciones. Algunas personas tenían referencias precisas, como el nombre del intérprete y del autor, e incluso conocían la melodía. También, y junto a ello, recordaban que por aquellos tiempos el suceso fue publicado por una revista de Buenos Aires ${ }^{27}$, cuyos ejemplares habrían llegado a Animaná.

Otros pobladores asociaron el evento a los conflictos familiares de los propietarios de la finca, basándose en distintas versiones que circularon en el pueblo y que establecían una directa relación entre uno y otro suceso. Según las versiones corrientes, el conflicto por el retraso de los sueldos se originó a causa de que "los patrones no se ponían de acuerdo", "tenían problemas respecto a la herencia" y a la administración de la finca y bodega. Los distintos relatos sobre el desarrollo de ese "problema" y sobre su desenlace señalan que hubo "un disparo", un intento de asesinato de

25 Esto ha sido abordado en otros trabajos (Villagrán, 2012 y 2014a).

26 En el año 2011 y en el marco de un proyecto financiando con una beca postdoctoral del Consejo Nacional de Investigaciones Científicas y Técnicas de Argentina, una de las autoras de este texto realizó la primera aproximación al lugar despertando sorpresa en los pobladores al preguntar sobre aquel suceso. Sin embargo, a la vez, estas mismas personas comentaban sobre otros visitantes que habían mostrado interés en aquel suceso: documentalistas y productores de televisión que habían buscado entrevistar a los protagonistas del "animanazo". El trabajo iniciado en 2011 luego se enmarcó en proyectos del Consejo de Investigación de la Universidad Nacional de Salta (CIUNSa N 2105) y de la Agencia Nacional de Promoción Científica y Tecnológica de Argentina (ANPCyT PICT N 2008-2084). Estos hicieron posible la organización de talleres y encuentros con algunos participantes de aquel suceso y sus familiares convocados por el SOEV. En ese ámbito surgió la iniciativa e inquietud, por parte de los participantes, de organizar una conmemoración del "Animanazo". La colaboración entre representantes de la Universidad Nacional de Salta, dirigentes del Sindicato y la Municipalidad de Animaná, permitió la realización del primer acto de conmemoración y de homenaje a los trabajadores vitivinícolas, que tuvo lugar el 19 de Julio de 2013 en la plaza principal de Animaná.

27 Se trata de la revista de difusión masiva Así. 
un integrante de la familia hacia otro, hecho que luego derivó en un suicidio. Esos comentarios resaltan el enfrentamiento abierto y declarado entre familiares, y las ambiciones y presiones de una parte interesada en "quedarse" con lo que le correspondería a la otra. La narración de los episodios se basa en una clara identificación de los actores, con sus respectivos nombres propios y la referencia de los vínculos de parentesco entre los implicados. Algunos relatores tomaban partido por uno u otro integrante de la familia, invistiendo de un mayor dramatismo a los hechos e interpretándolos como una tragedia en la cual es posible distinguir víctimas y victimarios.

A la vez, estos sucesos parecen advertir o indicar la llegada de un nuevo tiempo, donde se suceden distintos cambios, demarcando un antes y un después en la vida del pueblo. A partir de entonces se inicia un período que los pobladores califican como "malos tiempos", significativos para la vida de todos, en tanto a partir de allí la finca comenzó a "andar mal" y por ello se produjo el retraso e interrupción en el pago de los salarios. Olga, esposa de quien por entonces era dueño del negocio más importante del pueblo, señaló "que la situación se había vuelto insostenible", que llevaban casi tres meses sin recibir el pago de los sueldos. Todo el pueblo estaba endeudado, los negocios ya no vendían "al fiado" (es decir, a cuenta) y "las familias estaban desesperadas y ya nadie sabía qué hacer"28.

Algunos pobladores consultados coincidieron en señalar que después del "animanazo" ya no hubo problemas y que, una vez pagada la deuda, el conflicto terminó. Hay quien afirma que sufrió represalias por su participación en aquel suceso, habiendo sido despedido tras quedar identificada su adhesión a un sector de la familia propietaria, a la fracción que resultó perdedora en la contienda. Otros, en cambio, establecieron una directa asociación entre ese conflicto y las detenciones llevadas a cabo cuatros años después, al producirse el golpe de Estado en el año $1976^{29}$. Durante la dictadura militar los referentes sindicales que encabezaron el levantamiento fueron detenidos y permanecieron incomunicados cerca de un mes en Salta. Uno de ellos, el entonces secretario general del Sindicato de Obreros y Empleados Vitivinícolas (SOEV) de Cafayate, fue objeto de la más descarnada violencia y sometido a torturas ${ }^{30}$.

Podría decirse que en este entretejido fragmentario y difuso cobra entidad el "animanazo", enmarcado en los relatos sobre los conflictos familiares de los propietarios de la finca, en los recuerdos sobre la carencia y la necesidad y en la valoración de lo insostenible de la situación que desencadenó la movilización de los trabajadores. Asimismo, el cobro de peaje, el corte del camino y la olla común se entrelazan en un

28 Entrevista realizada con Olga en Octubre de 2011. En todos los casos se utilizan nombres de ficción para resguardar la identidad de los entrevistados.

29 El autodenominado Proceso de Organización Nacional se inicia cuando las fuerzas armadas mediante un golpe de estado asumen el gobierno en Argentina continuando con una práctica de sucesivas intervenciones militares. El gobierno de facto, que funcionó bajo la interrupción de todos los derechos civiles y constitucionales, se mantuvo desde 1976 hasta el retorno democrático de 1983. Ese período estuvo caracterizado principalmente por la persecución, detención, desaparición y asesinato de personas ligadas a organizaciones y partidos políticos y a la actividad sindical aunque también a ciudadanos sin adscripción o militancia política.

30 Se pudieron conocer detalles de su detención por los relatos que integran el expediente del juicio por la causa conocida como Ragone II, vinculada al secuestro y desaparición del ex gobernador de Salta, Miguel Ragone, en donde su hijo actuó como testigo. En esa causa, que tuvo sentencia el 30 de Junio de 2015, se juzgaron los delitos de privación ilegal de la libertad y homicidio, cometidos en perjuicio de 18 personas, una de ellas el entonces secretario del Sindicato de Trabajadores Vitivinícolas de Cafayate, Pablo Salomón Ríos. Este juicio comenzó a principios de diciembre de 2014 y declararon 77 testigos, durante los siete meses que duró la investigación sobre los delitos de lesa humanidad cometidos entre abril de 1975 y septiembre de 1976. 
relato que no tiene pretensiones de abarcar la totalidad del evento, configurando un registro de enunciados fragmentarios.

Este formato deriva del modo de reconstrucción del pasado que las memorias habilitan $^{31}$, donde, al estilo de un rompecabezas, desde el presente se conectan personas, hechos y lugares. En estas representaciones la referencia a acciones como cocinar, cortar la ruta y cobrar peaje se anudan a las figuras del fuego y la olla, y remiten a localizaciones específicas, a lugares tales como la entrada a la bodega, la salida para San Carlos, la comisaría, la municipalidad, "donde estaban los tres álamos" (tres árboles) como referenció el lugar del corte del camino don Lautaro ${ }^{32}$.

A través de los relatos y recuerdos de algunos de los protagonistas y de actuales habitantes de la comunidad, este evento se inscribe en una práctica de historización que puede considerarse como una instancia de "integración y recreación significativa del pasado desde el presente, a través de prácticas y nociones socioculturalmente específicas de temporalidad, agencia y causalidad" (Guber, 1994: 30). A la vez, estas prácticas, en sintonía con la propuesta de Halbwachs, pueden entenderse como inscriptas en marcos sociales que las habilitan o constriñen, ya que es allí donde se adquieren los recuerdos, se los evoca, reconoce y localiza. Los marcos son los instrumentos que la memoria utiliza para reconstruir una imagen del pasado acorde con la época dada y en consonancia con los pensamientos dominantes (Halbwachs, 2004 [1994]:10).

Entre las evocaciones significativas, la olla es la figura que condensa las acciones más elocuentes, las que posibilitaron paliar el hambre, desplegándose en la consecución de los ingredientes, en la preparación del fuego, de la sopa y del locro ${ }^{33}$, demostrándose allí la solidaridad y la voluntad de resolver y revertir colectivamente la situación de carencia y necesidad. A partir de ese elemento, la olla, se recrea la imagen de las mujeres cocinando, de algunos hombres cobrando peaje para conseguir dinero e ingredientes, y la de un grupo saliendo a cazar animales para aportar a ese alimento común.

Es sugerente que estos relatos enfaticen sobre las figuras y elementos centrales de la canción, en ambos casos sin la necesidad de constituir un relato que remita explícitamente a los episodios o busque ordenarlos o secuenciarlos. Sin embargo, a diferencia de la canción, las interpretaciones locales reconocen como móvil desencadenante del evento el retraso y la interrupción en el pago de los salarios de los trabajadores a la vez que identifican consecuencias, entre ellas la detención de los sindicalistas que lideraron los reclamos y el despido de algunos de los actores involucrados.

31 Diversos autores se esforzaron en establecer diferencias entre la producción del pasado que posibilita la historia y lo que sucede mediante la memoria. El posicionamiento más extremo tal vez sea el de Pierre Nora (1984), quien entiende la historia como una antimemoria y la memoria como una antihistoria. Desde esta perspectiva, la memoria estaría siempre viva, en evolución permanente, "abierta a la dialéctica del recuerdo y de la amnesia inconsciente de sus deformaciones sucesivas, vulnerable a todas las utilizaciones y manipulaciones, susceptible a largas latencias y repentinas revitalizaciones". La historia, por el contrario, sería "la reconstrucción, siempre problemática e incompleta, de lo que ya no es". La memoria sería un "fenómeno que actúa como lazo vivido en un presente eterno"; la historia una "representación del pasado". Porque es "afectiva y mágica, la memoria se alimentaría de recuerdos vagos, globales o flotantes, particulares o simbólicos, sensible a todas las transferencias, pantallas, censura o proyecciones. La historia se definiría por su vocación universal, mientras en cambio la memoria tendría su raíz en lo concreto, en el espacio, el gesto, la imagen y el objeto (Nora, 1984: 3).

32 Entrevista realizada en Octubre de 2011. Lautaro aún vive en el pueblo de Animaná, en uno de los tres barrios que lo componen, trabajó en la bodega hasta su jubilación, sucedida el mismo año de la entrevista y actualmente sigue cultivando uvas y elaborando vino destinado principalmente a su consumo.

33 Comida tradicional y popular de la región noroeste de Argentina, elaborada en base a maíz, zapallo y carne. 
En términos generales los estudios sociales recurren al análisis de los relatos como un medio para ingresar a la experiencia del pasado, concediéndole un lugar significativo a los silencios, omisiones u olvidos ${ }^{34}$. Para el caso que aquí nos ocupa, sin embargo, la representación fragmentaria y difusa en cuanto a los hechos, informa no solo sobre los complejos mecanismos y factores sociales que inciden para habilitar recuerdos y olvidos, sino también sobre la singularidad de estos procesos en donde una parte significativa de la experiencia escapa a la posibilidad de la narración. Ello implica considerar que hay dimensiones de la experiencia en las que intervienen y se conjugan instrumentos, recursos y técnicas que se expresan mediante soportes materiales variados, imágenes u otro tipo de textualidades no narrativas. Así, al reflexionar sobre la particularidad de los procesos de memoria activados en este caso - sus contextos y condiciones de posibilidad, el entrecruzamiento de formas singulares y propias de recordar y evocar, la sutil y sustantiva diferencia entre recordar y narrar-, advertimos la necesidad de ponderar los mecanismos, recursos y soportes a través de los cuales se despliegan, expresan y circulan las memorias ${ }^{35}$. Acorde a ello, el campo de estudio de la antropología de la memoria exploró el funcionamiento de los medios de producción y transmisión de conocimiento, atendiendo a las técnicas e instrumentos que en cada operación se ponen en juego. Entre ellos podría incluirse el canto, tal como en el caso aquí estudiado que involucra la circulación y apropiación de la canción "Fuego en Animaná".

En esa línea, Carlo Severi (2010) propone que las artes de la memoria ${ }^{36}$ conjugan imágenes, gestos y un modo específico de contar y celebrar inmersas en la compleja

34 Tal sería la propuesta de P. Ricoeur acerca de la narración como categoría epistemológica desarrollada especialmente en "La vida: un relato en busca de un narrador" (1984). En contraste con esa perspectiva centrada en la narración, los estudios de antropología de la experiencia, que remiten al trabajo fundante de Victor Turner y Edward Bruner The Anthropolgy of experience (1986), se centraron en la problemática relación entre experiencia y expresión, definiéndola como dialógica y dialéctica. Postulan que la experiencia viene a nosotros no solo verbalmente sino también en imágenes e impresiones, que hay experiencias que no son relatables, por tanto la brecha y la tensión entre realidad, experiencia y expresión se constituye en la problemática clave de la antropología de la experiencia. Las expresiones desde este encuadre pueden entenderse como articulaciones, formulaciones y representaciones acerca de la experiencia.

35 Desde algunas perspectivas de estudio sobre la construcción de memorias, como la de E. Jelin, se definió a éstas como productos culturales insertos en procesos subjetivos-activos de "transformación y elaboración de sentidos acerca del pasado", que suceden bajo la intervención de mecanismos y operaciones complejas, y que refieren tanto a lo que es "narrado" como a los "silencios", "olvidos", "actos" y "gestos' (Jelin, 2002: 17).

36 Severi propone superar la dicotómica distinción entre las sociedades occidentales europeas y no occidentales, las de la oralidad y las de la escritura, para avanzar en el entendimiento de las artes de la memoria desde el comparativismo y las situaciones mixtas donde se combinan lo "oral", "iconográfico" y "gestual". En la convivencia de las tradiciones orales y escritas se despliega un uso especial y sofisticado de la palabra dicha, que representa una estructura narrativa diferente, menos simple, relacionada con la organización de la memoria, un vínculo inesperado con el hecho mismo de enunciar, de comunicar con las palabras [...] que mantiene un nexo muy peculiar con el uso de las imágenes (2010: 43).

En esta línea, se pueden señalar estudios como los de Arnold y Yapita (1998), que tomaron como objeto las canciones, y específicamente las que circulan oralmente en comunidades andinas de Perú, Bolivia y Chile, al referirse a éstas como artificios de la memoria (y también artificios retóricos y didácticos). Resaltan el uso que hacen las mujeres de estas canciones para transmitir conocimientos particulares, donde el contenido temático está vinculado a la cartografía ecológica del universo (1998: 26). En otro trabajo, Arnold (2009), postula la centralidad de los textiles en las prácticas mnemónicas claves en los Andes. Allí se sostiene que los "caminos ordenados de la memoria" (los takhi), sirven como mapas cognitivos que tienen una relación dinámica con los procesos y las prácticas sociales que organizan el tiempo y el espacio (2009: 222). El concepto de cartografías de la memoria se inscribiría en un paradigma dinámico y viviente del espacio, donde los textiles se toman como artefactos implicados con el pensamiento, asumiendo que el textil provee un medio con qué pensar y un canal por medio del cual pensar (2009: 216). 
dinámica de la memoria y el olvido. Desde esa perspectiva es que se torna revelador el rol de la canción aquí abordada y se presenta como particularmente potente su estudio en el contexto de la conmemoración, por las posibilidades que generan este tipo de instancias sociales y por su capacidad para producir efectos, articular elementos e integrarlos significativamente.

\section{Conmemoración: canción y memorias}

La conmemoración del "animanazo" se inscribe en un contexto general que la posibilita, pues desde 2003 en adelante, a partir de la presidencia de N. Kirchner (20032007) se impulsó una política estatal de promoción de los derechos humanos y de juicio a los crímenes cometidos durante la última dictadura militar, mediante los cuales fueron condenados altos mandos de las fuerzas armadas. El conocimiento acerca del plan sistemático de detención y desaparición de personas no solo provocó la condena legal de estos hechos sino también fortaleció su repudio y condena social, los que se apuntalaron en acciones diversas en pos de la construcción de ciertas memorias públicas. Así, por ejemplo, el 24 de marzo se institucionalizó como feriado y día nacional de la memoria, por la verdad y la justicia, en conmemoración del inicio del autodenominado Proceso de Reorganización Nacional de 1976 (Ley N 25633).

En este escenario, un "momento oscuro y triste" del pasado, que se había mantenido bajo cierto manto de ocultamiento y silencio, empezó a ser re-significado, instalándose públicamente. Se impulsaron iniciativas sociales diversas, orientadas a "hacer memoria": entre ellas el señalamiento de parques, plazas y calles en distintas ciudades con nombres de desaparecidos, fechas o eventos vinculados a la dictadura - ese es el caso de los distintos episodios de "masacres" como Palomitas o Margarita Belén-, y además a rendir homenaje y reivindicar las "luchas sociales" y a "los luchadores" del pasado.

Ese clima se vivió en cada provincia de modo singular y con matices particulares, permitiendo fundamentalmente remover diversos aspectos y echar luz sobre sucesos y figuras locales vinculadas a ese pasado, localizado en los años 70, y a un momento tan significativo de la historia nacional. La función desempeñada a nivel local por ciertos actores políticos fue clave para propiciar instancias de recuperación, reconciliación y reivindicación de acontecimientos de ese carácter y de sus protagonistas. Ese es el caso de los actuales dirigentes del sindicato de trabajadores vitivinícolas de Cafayate y Animaná, para quienes "recuperar" las memorias del "animanazo" se constituyó en una apuesta no solo por el pasado sino principalmente por el presente y el futuro de los trabajadores de la vid.

La conmemoración de los 41 años del "animanazo", primer acto de homenaje y de celebración pública del aquel evento, propiciará así condiciones para traer aquel suceso al presente, re-significarlo y resituarlo en "la historia" local, dado que, tal como Connerton las entiende, este tipo de ceremonias conforman espacios privilegiados para la "transferencia de imágenes y conocimientos respecto al pasado" (1993:48). En tanto que rituales ${ }^{37}$, contienen una potencia específica: la capacidad

37 En ciertos estudios antropológicos clásicos, los rituales se asociaron a situaciones extraordinarias de gran importancia para la vida social, en virtud de los efectos simbólicos que pueden producir, de su potencial para la creación y actualización de representaciones sociales que servirían a los fines de la identificación colectiva. Su 
para articular elementos de una forma diferente y única, dado que los modos ordinarios de la comunicación corporal y gestual son transformados, asumiendo así un mayor grado de formalización y estilización (Bloch, 1989). En esto radica su carácter de "actos de gran complejidad y expresividad", que habilitan la comunicación y transmisión -implícita ó explicita- de mensajes incuestionables, capaces de hacer creer y generar cosas desde su celebración" (Moore y Myerhoff, 1977: 24).

Por tratarse del primer acto de conmemoración, se generaron grandes expectativas sobre éste. Desde tempranas horas del día 19 de Julio de 2013, y ya con varios días de antelación, el pueblo se preparaba para el acto que estaba por tener lugar, cuya organización implicaba la colaboración de distintos actores locales y externos. El epicentro estaría en la plaza principal del pueblo, que ya había sido puesta a tono para los festejos: iluminación y retoques de pintura en la fachada en algunos edificios; riego y ornamentación de los jardines. Se inauguraría esa noche un monolito y placa recordatoria, y en la sede del SOEV, ubicada frente a la plaza, una muestra fotográfica y de reproducciones de noticias periodísticas que llevaría por nombre "la sala del animanazo". Apenas iniciada la tarde, el ballet folklórico ensayó por última vez la coreografía con la cual representarían su homenaje al "animanazo". Trabajadores del municipio, en simultáneo, se encargaban del armado del escenario, realizaban las pruebas de sonido e iluminación y, en el patio del Sindicato, un grupo de mujeres se disponían a comenzar con la preparación del locro para compartir entre todos los asistentes, recreando la olla popular del año 1972. Esa misma mañana la radio local anunciaba el evento, mientras un protagonista del "animanazo" era entrevistado y su voz transmitida en vivo para toda la audiencia. En el diario más importante y de mayor tirada de Salta, ese acto de conmemoración fue publicitado en la página central.

Cerca de las 19 horas se dio inicio oficial al acto. Distintos oradores subieron al escenario, en una pautada y protocolar rutina, entre ellos el Intendente de Animaná, un representante de la Intendencia de Cafayate, el Secretario general de SOEV, Don Santos, un ex trabajador de la Finca - a quien se convocó para dar el testimonio de los protagonistas - y un docente de historia de Cafayate que oficiaría de narrador en off en la representación del ballet. La plaza estaba colmada de gente, ya que todos los habitantes de Animaná habían concurrido a la cita, aportando un clima de festejo.

El acto se ordenó en una sucesión de oradores, palabras alusivas y números artísticos. Entre ellos, las actuaciones más destacadas y que cobraron mayor centralidad fueron la intervención de Don Santos y la representación coreográfica en base a la canción "Fuego en Animaná".

Santos subió al escenario anunciado por el conductor del acto, quien lo presentó como "un protagonista que trae sus palabras", "humilde trabajador de la vid que trae su relato sobre lo que se vivió en aquellos tiempos". Frente al micrófono, Santos pronunció, entrecortadas, las primeras palabras:

"Buenas noches pueblo, pueblo de Animaná... que hemos ido al animanazo... porque no teníamos que comer seis meses... y nos dice el señor que nos anotaba a nosotros

capacidad comunicativa y expresiva contribuiría, de tal modo, al refuerzo de la cohesión grupal, alimentando sentimientos de pertenencia mediante la activación de símbolos. En otra línea de estudios, como Da Matta (2002), se sostuvo que en el ritual lo que sucede es más bien una síntesis y expresión, una condensación e integración de diversos elementos del orden cotidiano. 
la mercadería que no nos iba a dar más... ¿y qué hemos hecho nosotros?, a buscar el abogado del Sindicato...para que se haga el animanazo, y empezamos a estar juntos, permanecimos en olla popular, cazando loros para hacer... para que comamos nosotros y nuestros hijos, a traer guanacos para que también vayan a la olla ...y se empezó con el animanazo, y tomamos la intervención que tenía la bodega Michel y tomamos la policía, la sacamos a la intervención, y al otro día a mi me han destinado que tenía que cobrar un peaje, para tener para la leche, para los chicos, y empezamos a custodiar, y a la gente que venía de San Carlos tenía que sacarle yo el peaje, 5 pesos, y hacer que..., a la gente que venga de Cafayate le cobraba Angel Guaymas, que también era para leche, y después tomamos la escuela y ya después tomamos la municipalidad, tomamos la policía y todo esto nos ha pasado.

Y a la 1, 1:15, ha llegado a la bodega Cesar Perdiguero, el que nos ha tomado con el diario [periodista y poeta de Salta] y después salimos marchando ya para el Pueblo [a Cafayate], ahí venimos todos los trabajadores entonces... esa tarde misma ya han detenido a los compañeros del sindicato, Pablo Ríos, Inocencio Ramírez y los han llevado, y de allá [de Salta] ha venido otra vez el Doctor [asesor del sindicato] y para estar en el sindicato de Cafayate, porque en Cafayate creían que íbamos a tomar la municipalidad de Cafayate y estaba de inspector de zona de policía Santiago Guaymas... y nos han hecho llamá que vamos, ¿qué quiora van a ir?, y ya hemos salido en caravana...".

Santos finalizó su participación diciendo que después llegó el dinero de Salta para pagar lo que les adeudaban, y que eso había sido el "animanazo". Añadió, a modo de cierre, que también hubo trabajadores cesantes y despedidos por "el animanazo" y que esos "changos" tuvieron que ocuparse (emplearse) en otro lado. Santos fue convocado por los dirigentes del sindicato, y a ellos agradeció la invitación.

El Secretario General de SOEV, que fue otro de los oradores junto al Intendente de Animaná, en su intervención enfatizó que "recuperar la historia del animanazo" era de gran importancia no solo para conocer el pasado, sino principalmente para el presente, "para que los trabajadores sepan que han ganado esa lucha"...y que ésta había resultado así porque "estuvieron y pelearon juntos, unidos". Desde el sindicato se acentuó en el valor ejemplar de aquella experiencia de reclamo organizado, de aquella conquista, ya que recordar las luchas del pasado conformaba una oportunidad para denunciar las "injusticias" del presente, uniendo los reclamos de ayer y de hoy, y para hablar del atropello a los derechos de los trabajadores, el trabajo informal, la violación de los acuerdos salariales y los despidos.

En su participación, el orador que habló en nombre de los "protagonistas" — Don Santos - se dirigió al pueblo de Animaná y utilizó la expresión: "pueblo que hemos ido al animanazo", y a modo de cierre afirmó "esto es lo que nos ha pasado". En ese modo de relatar, de ordenar la narración, se puso de manifiesto que, si hasta ese momento había predominado entre el común de los pobladores una actitud de silenciamiento - que implicaba un cierto extrañamiento, negación y/o distanciamiento respecto de aquel evento y de ese pasado-, ya no era posible alegar desconocimiento o desmemoria. Enfáticamente afirmó que ese pasado les pertenece a todos, a cada uno de los "animanistos". Posicionado en el lugar de protagonista, Santos habló ante el público en nombre de todos los que no habían hablado, en representación de todas las voces, de los que ya no estaban porque murieron y, también, de los que están vi- 
vos pero aún no dieron testimonio. Aquello que por un largo período de tiempo había permanecido restringido y reservado a un espacio íntimo, familiar o privado, ahora era abiertamente expuesto para todos los presentes, transferido y delegado al pueblo entero. En esa instancia, una memoria resguardada y atesorada era transmitida, depositada y puesta en manos de los asistentes, de la comunidad en su conjunto. De tal modo, la recuperación de ese evento, propició su incorporación a una historia común y promovió una particular clave de re-significación.

Luego de la intervención de Santos — sin dudas el momento más emotivo y central de la conmemoración-, el acto prosiguió con la muestra y representación coreográfica del ballet folklórico "alma fuerte" 38 de la localidad de Cafayate. Este conjunto a través de la "danza rindió su homenaje al animanazo y a los trabajadores de la vid".

La puesta en escena se desplegó a través de cinco escenas, cada una de ellas compuestas en torno a la coreografía de baile - ejecutada por un conjunto de jóvenes procedentes de Animaná y Cafayate - y junto a ésta un repertorio de diferentes ritmos y temas de música folklórica con la voz de un relator en off —a quien le habrían comisionado la tarea de orientar la representación con un relato histórico de los sucesos - La escenografía recreaba el espacio de los cultivos de vid, y se habían dispuesto plantas sobre el piso de tierra y troncos de árboles, alrededor de los cuales transcurrirían el baile y la coreografía.

La primera escena representó y ubicó a los sujetos de aquel evento en su contexto, hombres y mujeres lugareños, vestidos con ropa de campesinos (sombreros, faldas y alpargatas), realizando las tareas de poda en la vid y acompañando los quehaceres con canto, guitarra y bombo. El relator completaba el sentido de la escena con el anuncio: "corría el año 1972".

La segunda escena se inició con el baile de un Gato, hacia el final de cual se introdujo el texto: "la situación de los trabajadores vitivinícolas era insoportable, la bodega no pagaba los salarios, los reclamos sindicales no eran escuchados... sufrían las familias, los niños...transcurrían ya largos seis meses de padecimiento..."

En la tercera escena ingresan los bailarines pancartas en mano, con inscripciones de los reclamos, a la vez que se oyen gritos de fondo y una voz que entona cánticos de protesta. Se acopla a la escena la voz del narrador en off que agregaba: “... el sentido de unidad y afán de lucha ya habían germinado en las conciencias..."

La cuarta escena inicia con el relato: "así dispusieron una movilización general que los condujo a tomar la bodega, el edificio municipal, la policía y cortar la ruta N 40" y continúa mencionando que “...Por la noche se encendían enormes fogatas para protegerse del frío invernal. También marcharon hacia Cafayate para reclamar la libertad de sus dirigentes", para remarcar que "Esta pueblada fue rescatada en el tema Fuego en Animaná, por Armando Tejada Gomez y Cesar Isella...”. Vemos así cómo la canción es apropiada y resignificada en el contexto celebratorio y ceremonial, adquiriendo el carácter de "himno" que los representa como comunidad y como pueblo.

La quinta escena transcurrió con la canción Fuego en Animaná sonando de fondo y como base de la coreografía. Los bailarines la representaron de un modo estilizado, alejándose de las formas propias o "típicas" de los tradicionales ballets. Los pasos

38 Ballet dirigido por Tomas Díaz, nieto de un participante del "Animanazo". El cuerpo de danza es un grupo no profesionalizado, ensaya semanalmente en la sede del Sindicato de Obreros y Empleados Vitivinícolas de Cafayate. 
y figuras, fluidas y de libre movimiento, se matizaron con elementos de las danzas contemporáneas en donde los cuerpos ganan expresividad.
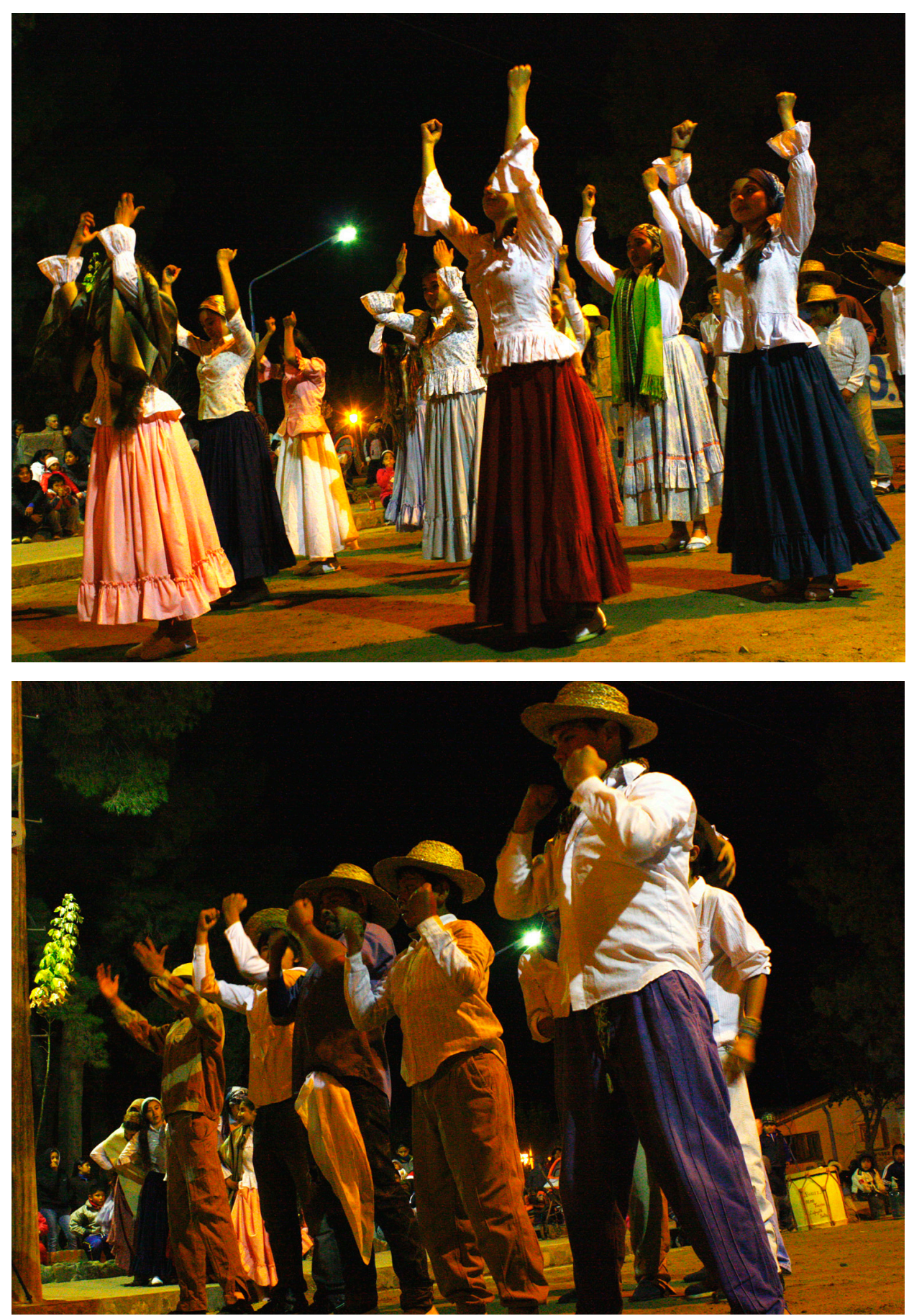

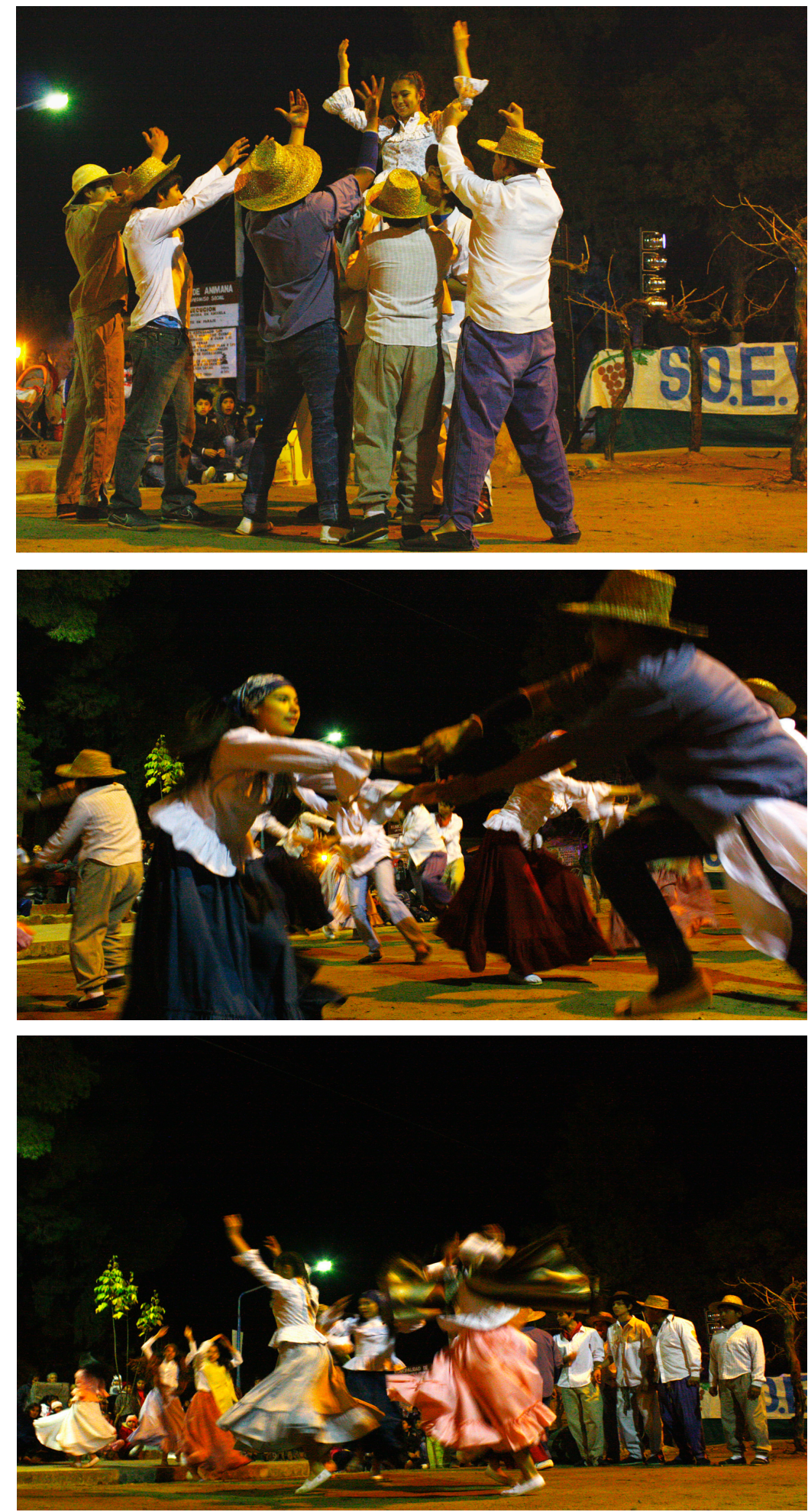
En la sexta escena imperó la voz en off del relator, que sostuvo: "transitamos el año 2013 y la lucha no ha terminado aún". Reseñó allí los principales problemas que afrontaban los trabajadores vitivinícolas en el presente, sus reivindicaciones y reclamos. Concluyó el bloque con un mensaje: "por ello se mantiene una actitud de movilización permanente y un estado de alerta ante las amenazas de despidos" [...] "el animanazo está considerado como el primer movimiento piquetero del país."

La representación coreográfica abrió la sección artística del acto, a la que siguió la actuación de una intérprete de baguala, quien no solo estaba presente allí para entregar su canto con caja como forma de homenaje, sino también en calidad de "protagonista del animanazo".

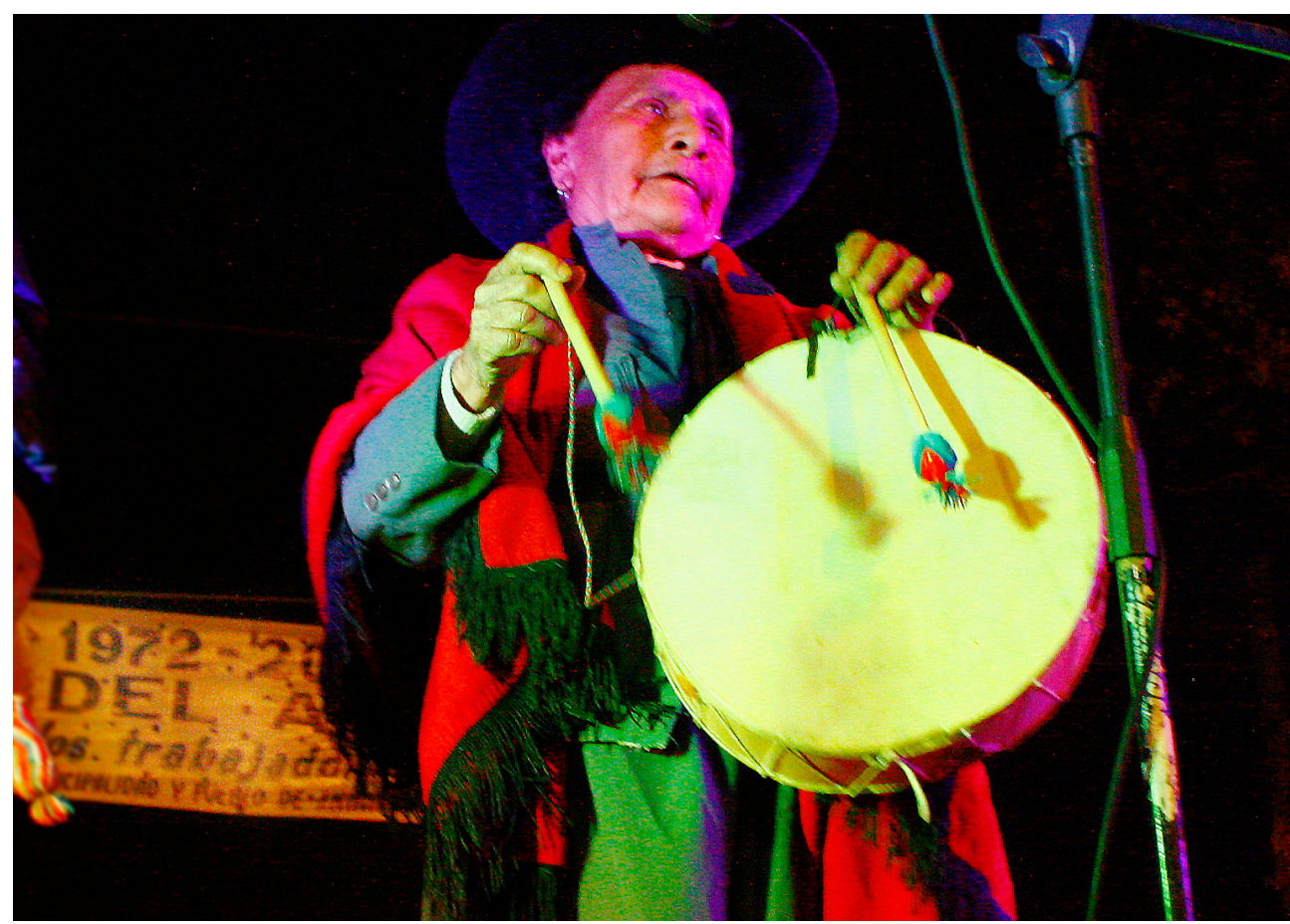

\section{Celebración y re-significación. A modo de comentarios finales}

Con el relato de Santos, el del narrador en off y la representación coreográfica de la canción "Fuego en Animaná", un proceso nuevo estaba en marcha. En éste, las lagunas y grietas en torno a ese pasado de lucha de los trabajadores habían sido simbólicamente suturadas mediante la narrativización y la performance ceremonial. Estaban habilitadas las vías de reconciliación con ese evento y con el pasado y su reinscripción, actualizada, en un nuevo contexto de reivindicaciones. Mediante este acto de representación singular propiciada por la operación conmemorativa, empezaba a articularse el conjunto de enunciados hasta entonces dispersos que estructuraban la versión pública de los hechos, que desde allí fue activada y promovida como un relato colectivo sobre "el animanazo". 
La fuerza y el potencial creador de la ceremonia y su carácter de expresión performativa estimuló la articulación intersubjetiva de aquella experiencia del pasado (Bruner, citado en Turner, 1989), mediante la memoria ritual y la voz cantada (Severi, 1996). Allí distintos elementos, hasta entonces desintegrados, pudieron ser coherentemente reunidos y ordenados en una secuenciación de hechos, mediante una performance que incluyó la representación corporal a través de la danza teatralizada, la recuperación de la canción y el desarrollo de un relato en off, posibilitando el ensamble de los distintos lenguajes y elementos para dar forma a un texto coherente cuya lógica de estructuración se anclaba en un elemento aglutinador: la marca de localidad, pertenencia e identificación, ser de Animaná.

Narración, canción y perfomance ceremonial dieron forma así a una explicación del evento en base al móvil desencadenante de la acción, una descripción de éstas y el repertorio llevado adelante, a la vez que informaba sobre los principales actores intervinientes y su final. En esa instancia, el "animanazo" empezó a ser objeto de una apropiación social extendida y generalizada, que consagró ritualmente a este evento como acontecimiento fundamental de la historia y del pasado de la comunidad. Ese contexto posibilitó que la canción transmutara simbólicamente a la condición de un himno de identificación local y afirmación de una pertenencia: "soy de Animaná". Al mismo tiempo, el uso de la canción en ese específico contexto permitió reactivar el potencial crítico, combativo y de denuncia de la canción, ya que su apropiación también apunta a destacar que aquello que desencadenó el "animanazo", movilizando al pueblo a luchar por una causa, constituye un motivo de convocatoria para continuar defendiendo las reivindicaciones laborales de los trabajadores de la vid en el presente. De tal manera, la canción se resignificó activándose nuevamente su función política, como instrumento que "agita conciencias" y convoca a la acción. Parafraseando la letra, su uso y circulación en ese presente permitió no sólo afirmar una pertenencia identitaria sino también realizar una advertencia: "sepan los que no han sabido que no estoy de solo estar" y que "la fogata en el Valle" tampoco "estaba de sólo estar".

\section{Referencias bibliográficas}

Arnold, Denise (2009). "Cartografías de la memoria: Hacia un paradigma más dinámico y viviente del espacio". en Cuadernos FHyCS-UNJu, N 36: 205-246.

Arnold, Denise y Yapita, Juan de Dios (1998). Río de vellón, río de canto. Cantar a los animales. Una poética andina de la creación. La Paz: Facultad de Humanidades de la Universidad Mayor de San Andres \& ILCA/Hisbol.

Bloch, Maurice (1989). Ritual, History and power: Selected papers in Anthropology. London: The Athlone Press Ltd.

Briones, Claudia (1994). “Con la tradición de todas las generaciones pasadas gravitando sobre la mente de los vivos. Usos del pasado e invención de la tradición”. Runa. Archivo para las ciencias del hombre: V (XXI), 99-129.

Bruner, Edward M. (1986). "Experience and its expressions" en Turner Victor y Bruner Edward M (Eds.), The Anthropology of experience, Urbana and Chicago: University of Illinois press, 3-30.

Castilla, Manuel (2015). Obras completas. Salta: Fondo Editorial, Secretaría de Cultura de la Provincia de Salta.

Cavarozzi, Marcelo y Gutierrez, Ricardo (1999). "La construcción política de una crisis: 
el gobierno peronista de 1973-1976" en Dutrénit Bielous, Silvia y Rodríguez de Ita, Guadalupe (Coord.). Asilo diplomático mexicano en el cono sur. México: Instituto MoraInstituto Romero.

Chamosa, Oscar (2012). Breve historia del folklore argentino 1920-1970: identidad, política y nación. Buenos Aires: Edhasa.

Connerton, Paul (1989). How Societies Remember. United Kingdom: Cambridge University Press.

Cortazar, Augusto Raúl (1967). "El folklore y su proyección literaria” en Capítulo. La historia de la literatura argentina, 57. Buenos Aires: CEAL.

Da Matta, Roberto (2002). Carnavales, malandros y héroes. Hacia una sociología del dilema brasilero. México-Rio de Janeiro: Zahar editores.

Das, Veena (1996). Critical Events. An anthropological perspective on Contemporary India. Oxford: University Press.

Diaz, Claudio (2009). Variaciones sobre el ser nacional. Una aproximación sociodiscursiva al folklore argentino. Córdoba: Ediciones Recoveco.

Fierstein, Daniel (2007). El genocidio como práctica social: entre el nazismo y la experiencia argentina. España: FCE.

Frith, Simon (2003). "Música e identidad" en Hall Stuart y Du Gay Paul (Comps.). Cuestiones de identidad cultural. Buenos Aires: Amorrortu, 181-213.

Gonzalez, Juan Pablo (2005). “Tradición, identidad y vanguardia en la música chilena de la década de 1960". Aiesthesis: 38, 193-213. [Fecha de consulta: 29 de septiembre de 2014] $<$ http://www.redalyc.org/articulo.oa?id=163221380014>

- (2007). “Abordaje de la Música Popular en el ámbito Académico: conflictos, debates, aportes, dicotomías, opiniones, sugerencias, experiencias, expectativas, logros". Paper presentado en I Congreso Latinoamericano de formación académica en música popular. Universidad Nacional de Villa María. [Fecha de consulta: 12 de Julio de 2014]. http://webnueva.unvm. edu.ar/webs/congresomusica1/Conferencias/02-Juan_Pablo_Gonzalez.pdf

Guber, Rosana (1994). "Hacia una antropología de la Producción de la Historia". Entrepasados: 6, IV, 23-32.

James, Daniel (Coord.) (2003). Nueva historia argentina. Violencia, proscripción y autoritarismo (1955-1976). Argentina: Sudamericana.

Halbwachs, Maurice (2004). [1994] Los marcos sociales de la memoria. Barcelona Chile-Venezuela: Anthropos en co-edición con la Facultad de Ciencias Sociales de la Universidad de Concepción (Chile). y la Facultad de Ciencias Económicas y Sociales de la Universidad Central de Venezuela.

Healey, Mark Alan (2003). "El interior en disputa: proyectos de desarrollo y movimientos de protesta en las regiones extrapampeanas "cap IV en JAMES, Daniel (Coord.). Nueva historia argentina. Violencia, proscripción y autoritarismo (1955-1976). Argentina: Sudamericana.

Jelin, Elizabeth (2002). Los trabajos de la memoria. España: Siglo XXI.

Kaliman, Ricardo (2003a). Alhajita es tu canto. El capital simbólico de Atahualpa Yupanqui. Tucumán: Universidad Nacional de Tucumán, Proyecto "Identidad y reproducción cultural en los Andes".

- (2003b). "Viña, luna, cielo y arena. El espacio calchaquí en el folclore argentino moderno". En Local, Regional, Global: prehistoria, protohistoria e historia en los Valles Calchaquíes. Cornell Per \& Stenborg Per (Eds.), Suecia: Instituto Iberoamericano y Universidad de Goteborg, 443-460.

- (2007). "Pisando la luna. Lo ilustrado y lo popular en Manuel J. Castilla" en María 
Eugenia Bestani \& Guillermo Siles (Comp.). La pequeña voz del mundo y otros ensayos. Poesía - Crítica - Traducción. Seminario Libre de Poesía "Juan Rodolfo Wilcock", Facultad de Filosofía y Letras UNT: Tucumán, 223-234.

- (2010). "El canto de la dicha verdadera. Pueblo y utopía en las letras del folklore en los '60 y los '70 en Tucumán”. En Fabiola Orquera (Ed). Ese ardiente Jardín de la República. Formación y desarticulación de un "campo" cultural: Tucumán, 1880-1975. Córdoba: Alción Editora, 295-318.

Kusch, Rodolfo (2007). Obras completas. Rosario: Editorial Fundación Ross.

López, Irene (2013). “Consideraciones sobre la canción como objeto de estudio”. Jornaleras. Revista cientifica de estudios literarios y lingüísticos. Año 1, $\mathrm{N}^{\mathrm{o}} 1$, Jujuy, Universidad Nacional de Jujuy. Disponible en: http://www.fhycs.unju.edu.ar/index.php/publicacione

Molinero, Carlos (2011). Militancia de la canción. Política en el canto folklórico de la Argentina (1944-1975). Buenos Aires: Ediciones de Aquí a la Vuelta.

Moore, Sally F., Myerhof, Bárbara G. (Eds.). (1977). Secular Ritual. Ámsterdam-The Netherlands: Van Gorcum.

Nora, Pierre (Dir.) (1984). Les Lieux de Mémoire, París, Gallimard: La République, XVIIXLIL. Traducción disponible en www.cholonautas.edu.pe / Módulo virtual: Memorias de la violencia.

Ricoeur, Paul (1984). "La vida: un relato en busca de un narrador" en Educación y política. Buenos Aires: Docencia, 45-58.

Sahlins, Marshall (1997 [1985]). Islas de historia. La muerte del capitán Cook. Metáfora, antropología e historia. Barcelona: Gedisa.

Severi, Carlo (1996). La memoria ritual. Locura e imagen del blanco en una tradición chamánica amerindia. Quito: Abya Yala.

- (2010). El sendero y la voz. Una antropología de la memoria. Buenos Aires: Sb.

Scotorin, Ramiro Daniel (2007). Salta Montonera. La actuación política de los sectores populares en la Provincia de Salta 1972-1976. Buenos Aires: CTA ediciones.

Trouillot, Michael R. (1995). Silencing the past. Power and the Production of History. Boston: Beacon press.

Turner, Victor (1990). La selva de los símbolos. España: Siglo XXI.

- (1998 [1969]) El proceso ritual. Estructura y antiestructura. Madrid: Taurus.

Vila, Pablo (1996). "Identidades narrativas y música. Una primera propuesta para entender sus relaciones". TRANS-Revista Transcultural de Música 2:14. [Fecha de consulta 20 de Septiembre de 2014]. http://www.sibetrans.com/trans/articulo/288/identidadesnarrativas-y-musica-una-primera-propuesta-para-entender-sus-relaciones

Villagrán, Andrea (2014a). "La finca”, el tiempo y los eventos en Animaná. Un acercamiento al pasado-presente de los Valles Calchaquíes, Salta. Memoria Americana. Cuadernos de Etnohistoria 23: 2 http://ppct.caicyt.gov.ar/index.php/memoria-americana

- (2014b). "Donde sobrevive soterradamente la tradición. El discurso folkórico y la región calchaquí". Ponencia presentada en Coloquio Internacional: La Selva, la Pampa, el Ande. Las vías interiores de la cultura argentina. Organizado por el ISES e INVELEC UNT/ CONICET, Tucumán.

- (2012). "Nociones morales, eventos críticos y entramados de poder en un espacio rural. El caso de la Fincas vitivinícolas de Argentina”, ponencia presentada en el XIV Congreso de Antropología. Universidad de Antioquia, Medellín-Colombia. 


\section{Anexos}

\section{Fuego en Animaná}

Dicen que yo, de solo estar, fui apagándome como la luz lenta y azul del atardecer

Piensan que estoy secando el sol de la soledad, que por estar en mi raíz ya no crezco más.

Es que yo soy, ése que soy, el mismo nomás, hombre que va buscándose en la eternidad.

Si es por saber de dónde soy, soy de Animaná.

\section{II}

Sepan lo que no han sabido que no estoy de sólo estar, que estoy parado en el grito Bagualero del Pujay.

\section{Recitado}

Ayer nomás ardió el pueblo por la tierra y por el pan, y la fogata en el valle no estaba por sólo estar.

I Si yo me voy, conmigo irá todo lo que soy.

Lejos de mí, lejos de aquí, yo no seré yo.

Déjenme estar, de sólo estar, viendo el sol volver.

Yo quiero ver en mi país

El amanecer.

Soy pa' durar, como el maíz, Simple y cereal.

Soy pa' durar, porque yo se pasar y pisar.

Si es por saber de dónde soy, soy de Animaná. 